\title{
Early diagnosis of rabies virus infection by RPA-CRISPR techniques in a rat model
}

\author{
Meishen Ren ${ }^{1,2} \cdot$ Hong Mei $^{1,2} \cdot$ Jiaojiao Zhou ${ }^{3} \cdot$ Ming Zhou $^{1,2} \cdot$ Heyou Han ${ }^{3} \cdot$ Ling Zhao $^{1,2}(\mathbb{D}$
}

Received: 29 September 2020 / Accepted: 7 December 2020 / Published online: 5 February 2021

(C) The Author(s), under exclusive licence to Springer-Verlag GmbH, AT part of Springer Nature 2021

\begin{abstract}
Rabies, which is caused by rabies virus (RABV), poses an ever-present threat to public health in most countries of the world. Once clinical signs appear, the mortality of rabies approaches $100 \%$. To date, no effective method for early rabies diagnosis has been developed. In this study, an RPA-CRISPR nucleic-acid-based assay was developed for early rabies diagnosis by detecting viral RNA shedding in the cerebrospinal fluid (CSF) of rats. This method can detect a single copy of RABV genomic RNA in $1 \mu \mathrm{L}$ of liquid. RABV genomic RNA released from viral particles in the CSF could be detected via RPA-CRISPR as early as 3 days postinfection in a rat model. This study provides an RPA-CRISPR technique for early detection of RABV with potential application in the clinical diagnosis of human rabies.
\end{abstract}

\section{Introduction}

Rabies is an old infectious disease with clinical signs of lethal encephalitis that poses a threat to public health worldwide [1]. More than 59,000 people reportedly die from rabies every year [2]. The disease is caused by rabies virus (RABV), a neurotropic virus belonging to the genus Lyssavirus in the family Rhabdoviridae that has a negative-sense single-stranded RNA genome that encodes five structural proteins.

In cases of rabies, the time between infection and the onset of signs is variable. Since its early clinical signs are often nonspecific, RABV infection may go undetected until the virus reaches the central nervous system (CNS) [3]. After being introduced by a bite from a rabid animal, RABV may maintain a low level of replication in muscle cells $[4$,

Handling Editor: William G Dundon.

Ling Zhao

zling604@yahoo.com

1 State Key Laboratory of Agricultural Microbiology, Huazhong Agricultural University, Wuhan 430070, China

2 Key Laboratory of Preventive Veterinary Medicine in Hubei Province, College of Veterinary Medicine, Huazhong Agricultural University, Wuhan 430070, China

3 State Key Laboratory of Agricultural Microbiology, College of Science, Huazhong Agricultural University, Wuhan 430070, China
5] before moving to the peripheral nervous system (PNS) and interacting with cell receptors, including the nicotinic acetylcholine receptor (nAChR), the neuronal cell adhesion molecule (NCAM), and the low-affinity nerve growth factor receptor (p75NTR) [6-10]. After invading the PNS by retrograde axonal transport, RABV replicates in the motor neurons of the spinal cord, finally entering the CNS [11]. Once the virus has entered the brain, there is no effective treatment, and mortality is $100 \%$, except for a few individual cases described in the literature [12-15].

Direct fluorescent antibody (DFA) and direct rapid immunohistochemistry (dRIT) tests are the primary diagnostic assays for RABV antigen identification in the CNS [16, 17]. RT-PCR and qPCR are also widely used, and their sensitivity and specificity for RABV are similar to those of DFA or dRIT [18-20]. These assays are reliable for detecting RABV in samples from hosts with mild-to-severe neurological signs [21-23]. However, they may not be sensitive enough to detect RABV in samples with low viral loads, particularly in the early stage of RABV infection.

Recently, recombinase polymerase amplification (RPA) and CRISPR-LwCas 13a collateral cleavage were combined to develop a highly sensitive nucleic acid detection method [24]. This combination assay was found to be capable of detecting Zika virus (ZIKV) at concentrations as low as 2 aM without compromising specificity [24]. This detection method has also been termed as "specific high-sensitivity enzymatic reporter unlocking" (SHERLOCK). HUDSON (heating unnextracted diagnostic samples to obliterate 
nucleases), a kind of sample treatment method, can be paired with RPA-CRISPR for viral detection directly from bodily fluids. Employing RPA-CRISPR in combination with HUDSON has allowed the direct detection of ZIKV from clinical samples of serum, urine, and saliva at concentrations as low as $3.2 \mathrm{aM}$ ( 2 copies/ $\mu \mathrm{L})$ [24]. To overcome the limitation of sensitivity, in the present study, an RPA-CRISPR detection method was applied for the early diagnosis of RABV infection. We applied the RPA-CRISPR technique to detect RABV before it reaches the brain in a rat model. Our study indicates that RPA-CRISPR is a reliable tool for the early diagnosis of RABV infection. This method has potential application for the early diagnosis of RABV infection in mammals, especially humans, and will provide a basis for timely clinical treatment for rabies.

\section{Materials and methods}

\section{Viruses, cells, plasmids, and animals}

CVS-B2c is an attenuated RABV strain that was derived from the mouse-adapted rabies strain CVS-24 by serial passaging in BHK-21 cells. RABV SAD-B19 is a widely used vaccine strain. DRV-Mexico is a wild-type RABV strain isolated from a rabid dog in Mexico. SHBRV is a bat-associated RABV strain isolated from a human patient. DRV-AH08 is a wild-type RABV strain isolated from a rabid dog from Anhui Province, China. DRV-HuNPN01 is a wildtype RABV strain isolated from a rabid pig from Hunan Province, China. References for the above RABV strains are listed in Table 1. Canine distemper virus (CDV) and canine parvovirus (CPV) were obtained from the animal hospital of Huazhong Agricultural University, Wuhan, China. Vesicular stomatitis virus (VSV) and Sendai virus (SeV) were obtained from Dr. Mingzhou Chen, Wuhan University,
China. Japanese encephalitis virus (JEV) was obtained from Dr. Shengbo Cao, Huazhong Agricultural University, China.

Mouse neuroblastoma (NA) cells were cultured in Dulbecco's modified Eagle's medium (DMEM) (Gibco, Grand Island, NY) containing $12 \%$ fetal bovine serum (FBS) (Gibco). BSR cells, derived from BHK-21 cells, were maintained in DMEM containing 10\% FBS. Human embryonic kidney 293T cells (HEK-293T) were cultured in DMEM containing $10 \%$ FBS.

An RABV-P-protein-specific monoclonal antibody was prepared in our laboratory as described previously [25]. Plasmid pC013-Twinstrep-SUMO-huLwCas13a (a LwCas13a bacterial expression vector) was obtained from Addgene (Addgene plasmid \# 90097; http://n2t.net/addge ne:90097; RRID: Addgene_90097) [24]. RABV CVS-B2c genomic backbone plasmid and helper plasmids were prepared in our laboratory as described previously [26].

Six-week-old female specific-pathogen-free (SPF) Sprague-Dawley (SD) rats were purchased from the Hubei Center for Disease Control, Wuhan, China. All animal experiments were performed in accordance with the Ministry of Science and Technology of China protocol for the care and use of laboratory animals and approved by the Scientific Ethics Committee of Huazhong Agricultural University (permit number HZAURA-2018-012).

\section{Preparation of CRISPR-LwCas13a protein}

E. coli BL21 (DE3) competent cells were transformed with the plasmid pC013-Twinstrep-SUMO-huLwCas13a and grown in LB medium (10 $\mathrm{g}$ of tryptone, $5 \mathrm{~g}$ of yeast extract, and $10 \mathrm{~g}$ of $\mathrm{NaCl}$ per liter; Sigma) at $37^{\circ} \mathrm{C}$ until reaching an $\mathrm{OD}_{600}$ of 0.6. Protein expression was then induced with 500 $\mu \mathrm{M}$ IPTG (Invitrogen), and the cells were incubated for an additional $16 \mathrm{~h}$ at $18{ }^{\circ} \mathrm{C}$. Cells were collected by centrifugation, resuspended in lysis buffer $(20 \mathrm{mM}$ Tris- $\mathrm{HCl}, 500 \mathrm{mM}$ $\mathrm{NaCl}, \mathrm{pH}$ 8.0) containing protease inhibitors (cOmplete ${ }^{\mathrm{TM}}$
Table 1 Analysis of mismatches in crRNA target regions of standard RABV strains and isolated wild-type strains

\begin{tabular}{llll}
\hline RABV strain & GenBank no. & Reference & No. of crRNA mixture mismatches \\
\hline CVS-B2c & HQ891318.1 & {$[42]$} & 0 (in crRNA-1) \\
SAD-B19 & M31046.1 & {$[43]$} & 0 (in crRNA-1) \\
DRV-Mexico & HQ450386.1 & {$[44]$} & 0 (in crRNA-1) \\
SHBRV & AY705373.1 & {$[45]$} & 0 (in crRNA-2) \\
DRV-AH08 & HQ450385.1 & {$[46]$} & 0 (in crRNA-3) \\
DRV-HuNPN01 & DQ496219.1 & {$[47]$} & 0 (in crRNA-3) \\
PV (wt) & AF357308.1 & {$[48]$} & 0 (in crRNA-1) \\
93127FRA (wt) & GU992320.1 & Unpublished & 0 (in crRNA-1) \\
JSTZ190314 (wt) & MN175989.1 & Unpublished & 0 (in crRNA-3) \\
ChDg (wt) & MG458321.1 & {$[49]$} & 0 (in crRNA-2) \\
TN186 (wt) & JQ685922.1 & {$[50]$} & 0 (in crRNA-2) \\
TX5168 (wt) & GU644758.1 & {$[51]$} & 0 (in crRNA-2) \\
1435 (wt) & AF394881.1 & {$[52]$} & \\
\hline
\end{tabular}


Protease Inhibitor Cocktail, Roche) and then lysed using a nano homogenizer (ATS Engineering Inc.) at a pressure of $600 \mathrm{bar}$. After the lysate was centrifuged for $50 \mathrm{~min}$ at $13,000 \times g$, the supernatant was collected and filtered using a $0.22-\mu \mathrm{m}$ filter (Millipore). The filtrate was purified using an NGC Quest 100 protein purification system (Bio-Rad) fitted with a HisTrap FF Column (GE Healthcare Life Sciences). The purified protein was digested by SUMO protease (Invitrogen) overnight at $4{ }^{\circ} \mathrm{C}$ and then further purified using a Superdex ${ }^{\circledR} 200$ gel filtration column (GE Healthcare Life Sciences). After the fractions of interest were identified by SDS-PAGE, the fractionation buffer was replaced with storage buffer $(600 \mathrm{mM} \mathrm{NaCl}, 50 \mathrm{mM}$ Tris- $\mathrm{HCl}, 5 \%$ glycerol, $\mathrm{pH}$ 7.5), and the fractions were stored at $-80{ }^{\circ} \mathrm{C}$ until use.

\section{Preparation of RABV ssRNA and crRNAs}

RABV ssRNA was transcribed from a dsDNA template (a 1353-bp fragment in the coding sequence of the RABV N gene) using a HiScribe ${ }^{\mathrm{TM}}$ T7 High Yield RNA Synthesis Kit (New England Biolabs). This dsDNA template was amplified using the forward primer 5'-TAATACGACTCA CTATAGGGATGGATGCCGACAAGATTGTG-3' and the reverse primer 5'-TTATGAGTCATTCGAATACGTCTT GTT-3'. Using the same kit, the crRNAs of LwCas13a were transcribed from previously synthesized (Invitrogen) dsDNA fragments (crRNA-1, 5' -TAATACGACTCACTATAGGGG GATTTAGACTACCCCAAAAACGAAACTAGGGGA AACTCRTAGGTTCCGGCCAAAAMTCTGAAGT-3'; crRNA-2, 5'-TAATACGACTCACTATAGGGGGATTTA GACTACCCCAAAAACGAAACTAGGGGAAACTCA TAGGTTCCAGCTAGGAATCTGAAGT-3'; crRNA-3, 5'-TAATACGACTCACTATAGGGGGATTTAGACTAC CCCAAAAACGAAACTAGGGGAAACTCGTAGGTT CCAGCTAAGAATCTGAAGT-3'). The transcription products were digested with DNase I for $1 \mathrm{~h}$ at $37^{\circ} \mathrm{C}$ to degrade the dsDNA template and then extracted with TRIzol Reagent (Invitrogen).

\section{Collateral detection combining RPA and CRISPR-LwCas13a}

The RPA forward primer contained a T7 transcription region and the target region 5'-TAATACGACTCACTATAG GGARMTYGTRGARCAYCAYACHYTAATGACAAC-3', and the reverse primer contained just the target region 5'GCYGAATAVAGATGYTCAATCCGNGAGAAAA-3'. The RPA reaction consisted of $25 \mu \mathrm{L}$ of $2 \times$ Reaction Buffer, $5 \mu \mathrm{L}$ of $10 \times$ Basic E-mix, $2.5 \mu \mathrm{L}$ of $20 \times$ Core Reaction Mix, $1 \mu \mathrm{L}$ of 50× RT Mix (TwistAmp® Liquid Basic, TwistDx), 3.6 $\mu \mathrm{L}$ of dNTPs $(25 \mathrm{mM}), 2.5 \mu \mathrm{L}$ of forward primer $(100 \mu \mathrm{M}), 2.5$ $\mu \mathrm{L}$ of reverse primer $(100 \mu \mathrm{M}), 0.5 \mu \mathrm{L}$ of RNase inhibitor (New England Biolabs), $1 \mu \mathrm{L}$ of $\mathrm{MgCl}_{2}(250 \mathrm{mM}), 2.5 \mu \mathrm{L}$ of NTP buffer, $0.5 \mu \mathrm{L}$ of T7 Mix (New England Biolabs), 1 $\mu \mathrm{L}$ of RNA reporter $(10 \mu \mathrm{M})$ (5'-FAM-UUUUU-BHQ-3'), 1400 ng of CRISPR-LwCas13a, 480 ng of crRNAs (a mixture containing crRNA-1, crRNA-2, and crRNA-3 in equal proportions), $2.5 \mu \mathrm{L}$ of $\mathrm{MgOAc}(280 \mathrm{mM})$, and RNA template in a total volume of $50 \mu \mathrm{L}$. Reactions were incubated at $37{ }^{\circ} \mathrm{C}$ in a CFX96 Real-Time System (Bio-Rad) with a FAM fluorescent signal detected every minute.

\section{Combination of HUDSON and RPA-CRISPR}

For direct detection of RABV viral genomic RNA (vRNA) released from viral particles in cerebrospinal fluid (CSF) samples, the HUDSON method was used to lyse viral particles and inactivate ribonucleases [27]. Tris (2-carboxyethyl) phosphine hydrochloride (Sigma) and EDTA (Sigma) were added to a single CSF solution containing RABV particles to a final concentration of $100 \mathrm{mM}$ and $1 \mathrm{mM}$, respectively. Inactivation for $20 \mathrm{~min}$ at $50^{\circ} \mathrm{C}$ was followed by lysis for $5 \mathrm{~min}$ at $95{ }^{\circ} \mathrm{C}$ in a thermocycler. The sample solution was used directly as template for RPA-CRISPR.

\section{Quantitative RT-PCR (qPCR)}

The qPCR protocol was developed according to some wellestablished qPCR methods and a recommended assay in the OIE Terrestrial Manual [18, 28, 29]. vRNA was extracted using TRIzol Reagent (Invitrogen) and was reverse transcribed into cDNA using an FSQ-201 ReverTra Ace kit (TOYOBO). RABV vRNA levels were quantified using the forward primer 5'-AGCATACAGGCTTGACTCCG-3' and the reverse primer 5'-ACATCCAAGAGGCTCAAAATGT3', which anneal to the noncoding regions of the RABV genome. The forward primer 5'-AGAGCAGATTTTCGA GACAGC-3' and the reverse primer 5'-GGTTCCGGCCAA AAATCTGAA-3' were used to quantify the transcribed ssRNA; each $10-\mu \mathrm{L}$ reaction consisted of $5 \mu \mathrm{L}$ of $2 \times$ SYBR Green (Bio-Rad), $1 \mu \mathrm{L}$ of forward primer $(0.75 \mu \mathrm{M}), 1 \mu \mathrm{L}$ of reverse primer $(0.75 \mu \mathrm{M}), 1 \mu \mathrm{L}$ of cDNA template, and $2 \mu \mathrm{L}$ of $\mathrm{ddH}_{2} \mathrm{O}$. All reactions were performed on a CFX96 Real-Time System (Bio-Rad) using the following conditions: $95^{\circ} \mathrm{C}$ for $5 \mathrm{~min}$, followed by 40 cycles of $95^{\circ} \mathrm{C}$ for $15 \mathrm{~s}$ and $60{ }^{\circ} \mathrm{C}$ for $30 \mathrm{~s}$.

\section{Virus titration}

Viral titers were determined by DFA. Briefly, tenfold serial dilutions of viral supernatant were inoculated onto BSR cells in 96-well plates in quadruplicate and then incubated for $48 \mathrm{~h}$ at $37{ }^{\circ} \mathrm{C}$. Cells were fixed with $80 \%$ acetone and then incubated with an FITC-conjugated P-protein-specific mouse monoclonal antibody $(1: 500)$ for $1 \mathrm{~h}$ at $37^{\circ} \mathrm{C}$. Antigen-positive cells were visualized using an IX51 Olympus 
fluorescence microscope. Virus titers were calculated and presented as numbers of focus-forming units per milliliter (FFU/ml) as described previously [12].

\section{Early diagnosis of RABV in rat CSF}

Thirty-three six-week-old female rats were randomly divided into 11 groups with three rats per group. Five groups of rats were inoculated intramuscularly (i.m.) with 100 times the $50 \%$ lethal dose $\left(\mathrm{LD}_{50}\right)$ of RABV-CVS in $100 \mu \mathrm{L}$ of DMEM. Another five groups were i.m. inoculated with $100 \times \mathrm{LD}_{50}$ of RABV-DRV in $100 \mu \mathrm{L}$ of DMEM. One group of rats was i.m. injected with $100 \mu \mathrm{L}$ of saline as a mock-infection control. From 3 to 7 days post infection (dpi), one group of RABV-infected rats was taken every other day to collect CSF (50 $\mu \mathrm{L}$ per rat) for early diagnosis by RPA-CRISPR test.

\section{Statistical analysis}

GraphPad Prism 8 (GraphPad Software, Inc., CA) was used for data analysis. An unpaired two-tailed Student's $t$-test was used to test for significant differences. Kaplan-Meier survival curves were used to determine the statistical significance of the survivor ratio in the $\mathrm{LD}_{50}$ assays. Statistically significant differences are denoted as *, $P<0.05$; **, $P<$ $0.01 ; * *, P<0.001$; and $* * * *, P<0.0001$.

\section{Results}

\section{Construction and optimization of the RPA-CRISPR system}

RPA-CRISPR consists of recombinase polymerase amplification (RPA) followed by T7 transcription and collateral cleavage by CRISPR-LwCas13a (Fig. 1A). The optimal amounts of crRNA and CRISPR-LwCas13a, determined by titration, were $480 \mathrm{ng}$ of crRNA mixture (Fig. 1B) and 1400 ng of CRISPR-LwCas13a protein per tube (Fig. 1C).

\section{Sensitivity of the RPA-CRISPR system}

The limits of detection for RPA-CRISPR and qPCR were determined using serial dilutions of RABV genomic RNA (vRNA) and ssRNA. ssRNA was transcribed from a 1353-bp dsDNA fragment within the coding sequence of the RABV $\mathrm{N}$ protein. RPA-CRISPR was sensitive to $1 \mathrm{copy} / \mu \mathrm{L}$ for both vRNA and ssRNA (Fig. 2A and B), and qPCR was sensitive to 100 copies/ $\mu \mathrm{L}$ for vRNA (Fig. $2 \mathrm{C}$ ) and 10 copies $/ \mu \mathrm{L}$ for ssRNA (Fig. 2D).

\section{Combination of the HUDSON and RPA-CRISPR techniques}

For RPA-CRISPR detection, the HUDSON method was used to release viral RNA from viral particles in CSF samples [27]. Both RABV vRNA and viral particles were serially diluted tenfold using CSF collected from SD rats as dilution buffer and subjected to RPA-CRISPR. The results revealed that the level of sensitivity of RPA-CRISPR to vRNA and viral particles was $10^{0.5}$ copies $/ \mu \mathrm{L}$ and $10^{0.5} \mathrm{FFU} / \mu \mathrm{L}$, respectively (Fig. 3A and B).

\section{Specificity of RPA-CRISPR}

To evaluate the specificity of RPA-CRISPR, six RABV strains (CVS-B2c, SAD-B19, SHBRV, DRV-Mexico, DRVAH08, and DRV-HuNPN01), five other RNA viruses (CDV, CPV, SeV, JEV, VSV), and two mock-infected cell types (293T and NA) were used as templates for RPA-CRISPR detection. The crRNA mixture was composed so as to ensure that all RABV strains could be detected, with complementary sequences of the RABV strains included in the crRNA mixture with no mismatch in the target regions of standard RABV strains or wild-type strains (Table 1). The results showed that RPA-CRISPR accurately detected the RABV strains with no cross-reactivity (Fig. 3C).

\section{Early diagnosis of RABV infection by RPA-CRISPR in a rat model}

Early diagnosis of rabies is a prerequisite for timely treatment but remains a large challenge for researchers. Thus, we tested the ability of RPA-CRISPR to achieve early detection in a rat model. A schematic of the strategy is shown in Fig. 4A. CSF samples from RABV-infected or mock-infected rats were collected on the indicated days post infection and subjected to RPA-CRISPR. The results showed that RABVCVS and RABV-DRV strains were detected as early as $3 \mathrm{dpi}$ by RPA-CRISPR (Fig. 4B and C). However, by the qPCR method, the earliest that RABV was detected in CSF was 5 dpi (Table 2). The rats used for RPA-CRISPR were housed until clinical signs of rabies infection were evident, at which point they were euthanized, and their brains were collected for RABV vRNA detection by qPCR (Table 3 ).

\section{Discussion}

There remain numerous limitations to the early diagnosis of rabies. Before invading the brain, RABV replicates slowly, making it difficult to detect by traditional methods. Due to its high sensitivity, RPA-CRISPR has been increasingly used for detecting nucleic acids of viruses, parasites, and cancer 


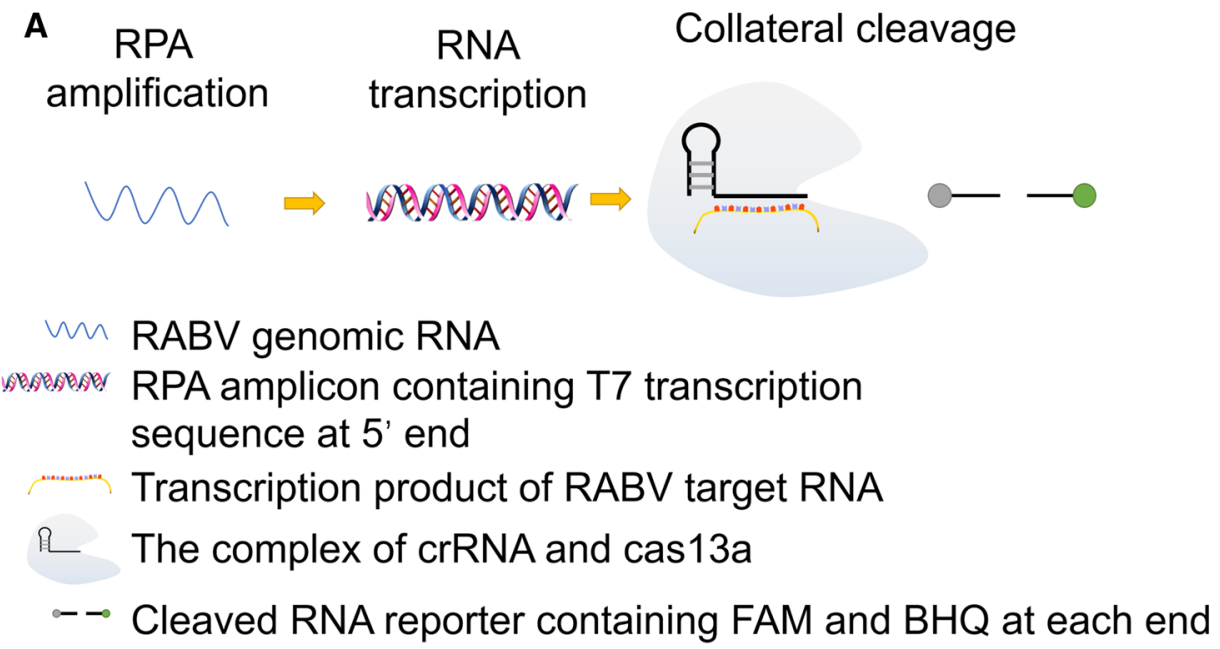

B

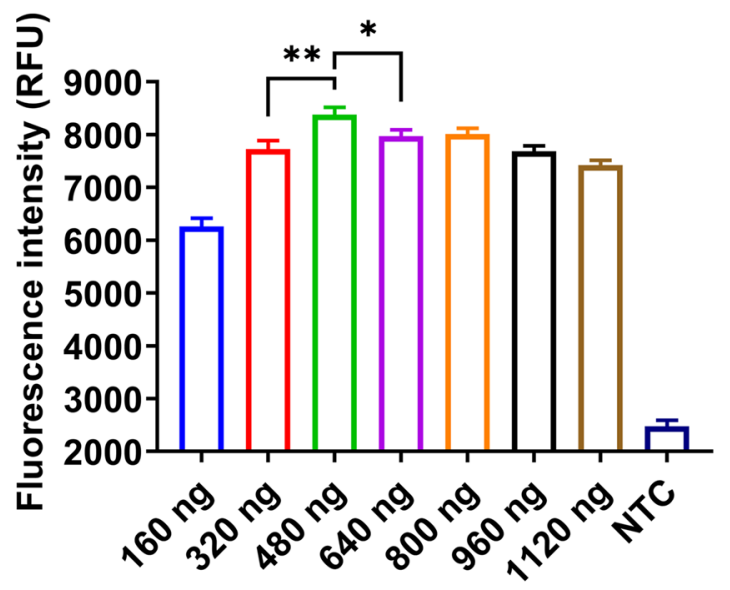

Fig. 1 Validation and optimization of the RPA-CRISPR system. (A) The process of RPA-CRISPR detection. (B) Titration of crRNA and (C) CRISPR-LwCas13a for optimizing the RPA-CRISPR reaction. Gradient dilutions of crRNA mixture (160 ng, 320 ng, 480 ng, 640 ng, $800 \mathrm{ng}, 960 \mathrm{ng}, 1120 \mathrm{ng}$ ) and CRISPR-LwCas13a (350 ng, 700

cells [24, 30-35]. Most recently, RPA-CRISPR was applied to the diagnosis of infection with the betacoronavirus severe acute respiratory syndrome coronavirus 2 (SARS-CoV-2) [36-38]. Some extended applications have been described, such as field-deployable diagnostics, single-nucleotide polymorphism (SNP) detection, miRNA quantification, and species identification in ecological studies [24, 27, 39, 40]. In this study, an RPA-CRISPR method was developed for the early diagnosis of RABV infection in a rat model.

Because of its high specificity and reliability, the direct fluorescent antibody test is the gold standard assay for rabies diagnosis [17]. The sensitivity of the DFA test depends on the freshness of the specimen and the degree of autolysis. In many cases, the sensitivity of the DFA test is lower than

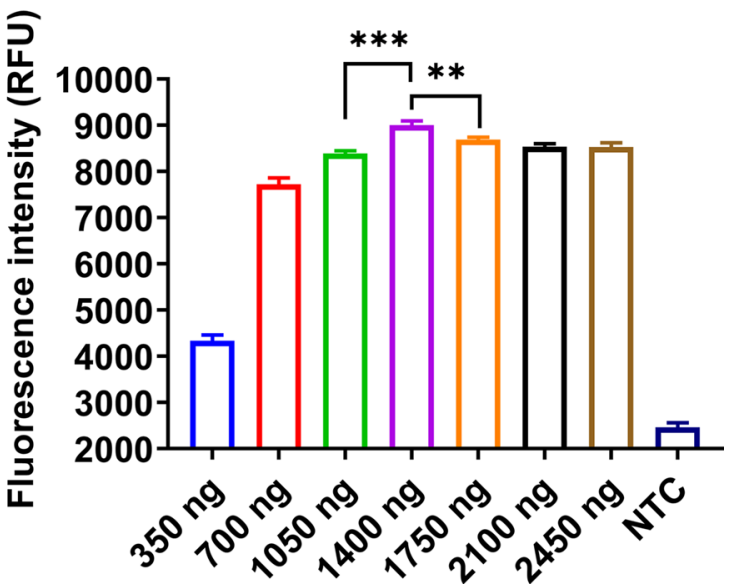

ng, $1050 \mathrm{ng}, 1400 \mathrm{ng}, 1750 \mathrm{ng}, 2100 \mathrm{ng}, 2450 \mathrm{ng}$ ) were used for optimizing the RPA-CRISPR reaction system. PBS was used as a control in the NTC groups. The bar graph shows the mean \pm stardard deviation $(\mathrm{SD})(\mathrm{n}=3)$. *,$P<0.05 ; * *, P<0.01 ; * * *, P<0.001$

that of PCR and qPCR [41]. Conventional PCR and qPCR used for measuring viral RNA have detection limits ranging from $10^{2}$ copies $/ \mu \mathrm{L}$ to $10^{1}$ copies/ $\mu \mathrm{L}[18,29]$. In contrast, the RPA-CRISPR method developed in this study is very sensitive and can detect viral RNA at concentrations as low as a single copy per microliter.

As we reported previously, mild clinical signs such as weight loss began to appear at 6 or 7 dpi [25] in RABVinfected mice. By that time, the virus had already invaded the brain. Early diagnosis may allow for the timely initiation of appropriate treatment and increase the chance of recovery. For early diagnosis, RPA-CRISPR or other methods targeting either viral RNA or viral antigens could be used. However, the viral load in the early stage of infection is 
Fig. 2 Sensitivity comparison between RPA-CRISPR and qPCR. (A) Titration of RABV vRNA and (B) ssRNA for determining the detection limits of RPA-CRISPR. Tenfold gradient dilutions of RABV vRNA and ssRNA were used for RPACRISPR sensitivity validation. (C) Titration of RABV vRNA and (D) ssRNA for determining the detection limits of qPCR. Tenfold gradient dilutions of RABV vRNA and ssRNA were used for qPCR sensitivity validation. PBS was used as a control in the NTC groups. The bar graph shows the mean \pm $\mathrm{SD}(\mathrm{n}=3) . *, P<0.05 ; * *, P$ $<0.01$; ***, $P<0.001$; ****, $P<0.0001 ;$ ns, no significant difference
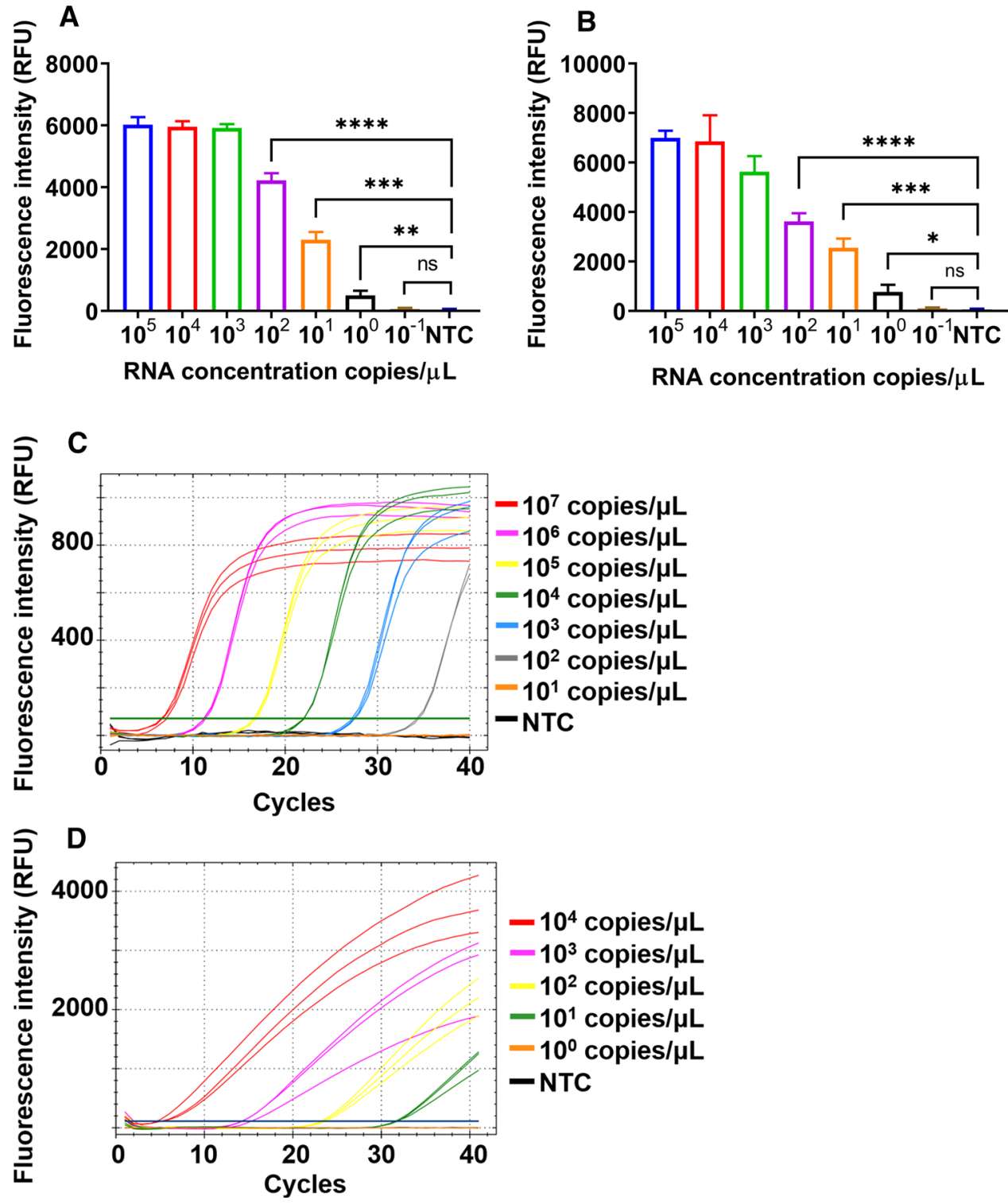

extremely low. Furthermore, false-negative detection results may be obtained due to the limitation of sensitivity. The RPA-CRISPR system is suitable for testing of low-viral-load samples due to its high sensitivity. According to our results, RPA-CRISPR could detect viral RNA in CSF samples as early as 3 dpi (Fig. 4B), demonstrating that RPA-CRISPR is a potential tool for early diagnosis of RABV infection.

Despite its superior sensitivity, RPA-CRISPR has some limitations. The RPA amplification component depends on the availability of optimal primers. However, no primer design tool is available to predict the amplification performance in the RPA reaction. Therefore, stringent primer screening should be performed before sample analysis by RPA-CRISPR.

In summary, we report that RPA-CRISPR can accurately detect $\mathrm{RABV}$ in the CSF of infected rats during the early stage of infection. RPA-CRISPR has great potential for application in the early diagnosis of RABV infection in mammals, especially humans. 

method and RPA-CRISPR. (A) RABV vRNA and (B) viral particles were serially diluted tenfold using CSF collected from specific-pathogen-free (SPF) Sprague-Dawley (SD) rats as dilution buffer for RPACRISPR detection. (C) The specificity of RPA-CRISPR was tested using different RABV strains (CVS-B2c, SAD-B19, DRV-Mexico, SHBRV, DRVAH08 and DRV-HuNPN01), canine viruses (canine distemper virus $[\mathrm{CDV}]$ and canine viruses (Sendai virus [SeV], Japanese encephalitis virus [JEV], vesicular stomatitis virus [VSV]), and human embryonic kidney 293T cells (293T) and mouse neuroblastoma cells (NA). PBS was used as a control in the NTC groups. The bar graph shows the mean $\pm \mathrm{SD}$ (n $=3$ ). ****, $P<0.0001$; ns, no significant difference
Fig. 3 Pairing the HUDSON parvovirus [CPV]), other RNA
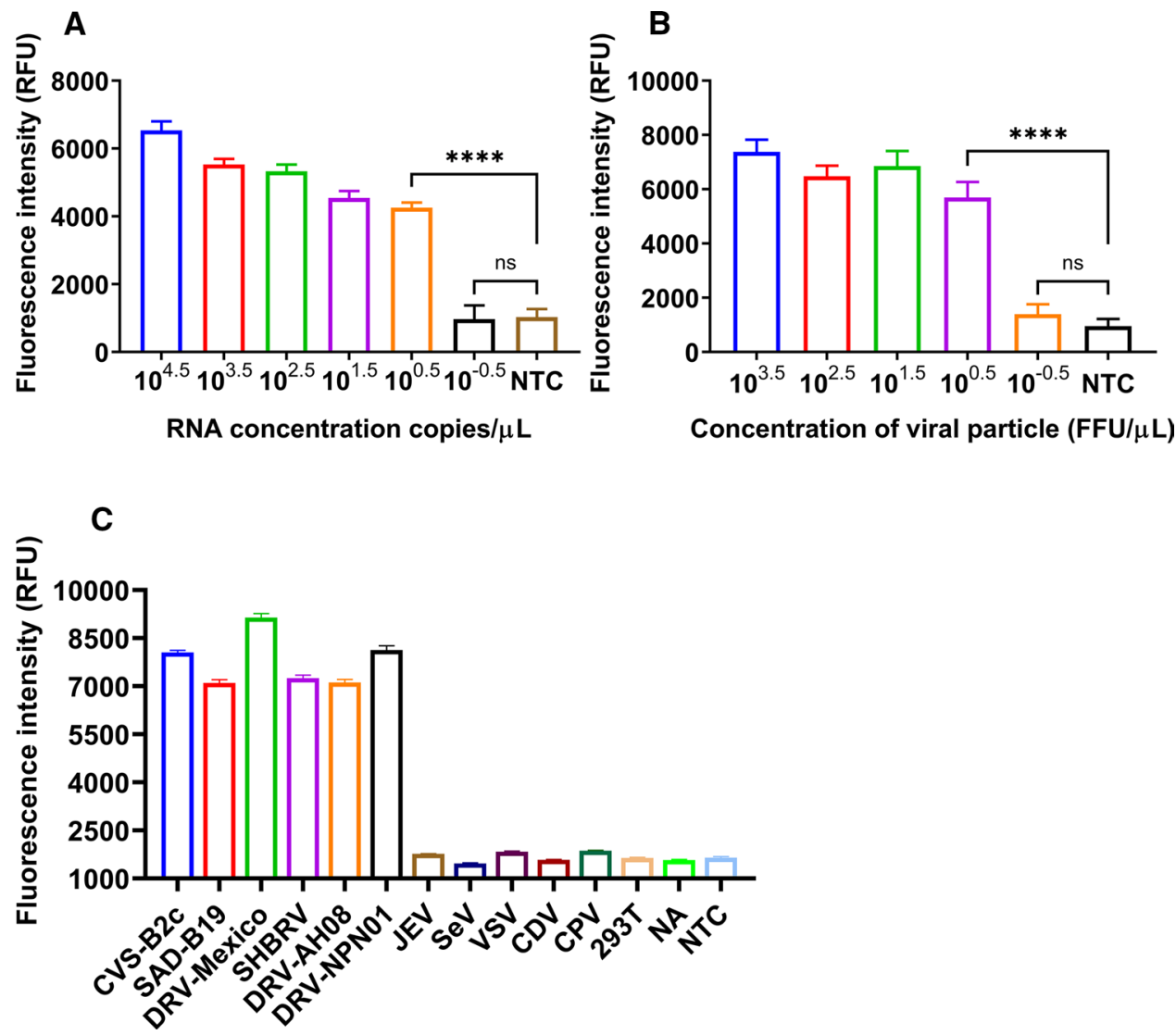

Fig. 4 Early diagnosis of RABV infection by RPA-CRISPR in a rat model. (A) Schematic of early diagnosis of RABV infection in a rat model. Thirtythree six-week-old SD rats were randomly divided into 11 groups with three rats per group. (B, C) Five groups of rats were i.m. inoculated with $100 \mathrm{LD}_{50}$ of lab-attenuated RABV strain CVS-B2c (B). Another five groups of rats were i.m. inoculated with $100 \mathrm{LD}_{50}$ of wild-type RABV strain DRVMexico (C). The mock infection group was i.m. inoculated with the same volume of DMEM. From 3 to $7 \mathrm{dpi}$, one group of infected rats was taken every other day to collect CSF $(50 \mu \mathrm{L}$ per rat). At each of the indicated days postinfection, CSF from a group of rats was subjected to RPA-CRISPR analysis. PBS was used as control in the NTC group. The bar graph shows the mean \pm standard error (SE) ( $\mathrm{n}$ $=3$ ).
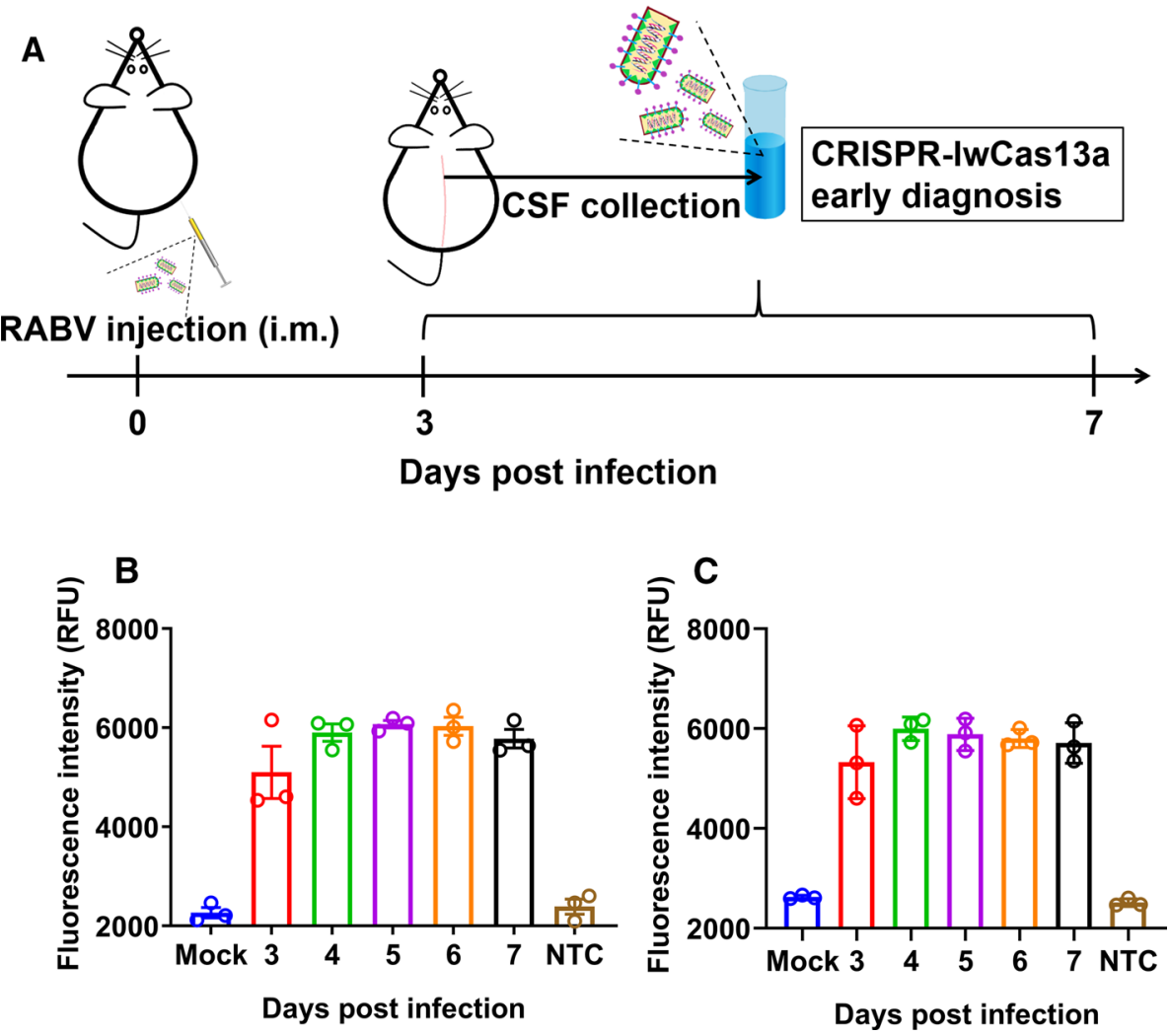
Table 2 Viral genomic RNA in rat CSF analyzed by qPCR at 3-7 days postinfection (dpi)

\begin{tabular}{lllllll}
\hline dpi. & Mock & 3 & 4 & 5 & 6 & 7 \\
\hline Ct & N/A & N/A & N/A & 35.43 & 29.32 & 25.33 \\
& N/A & N/A & N/A & 33.29 & 28.78 & 25.41 \\
& N/A & N/A & N/A & 36.78 & 29.87 & 25.87 \\
\hline
\end{tabular}

Table 3 Viral genomic RNA in the rat brain analyzed by qPCR at the moribund stage

\begin{tabular}{lllllll}
\hline Group & Mock & $3 \mathrm{dpi}$ & $4 \mathrm{dpi}$ & $5 \mathrm{dpi}$ & $6 \mathrm{dpi}$ & $7 \mathrm{dpi}$ \\
\hline Ct & N/A & 16.49 & 13.73 & 15.77 & 19.33 & 16.22 \\
& N/A & 14.36 & 16.55 & 17.76 & 14.38 & 14.76 \\
& N/A & 17.62 & 17.39 & 15.76 & 15.78 & 13.45 \\
\hline
\end{tabular}

Acknowledgements This research was supported by the National Program for Key Research Projects of China (2016YFD0500400 to L.Z.), the Fundamental Research Funds for the Central Universities (2662015PY227 to L.Z.), and the National Natural Science Foundation of China (31872451 to L.Z.).

\section{Compliance with ethical standards}

Conflict of interest The authors declare no potential conflicts of interest with respect to the research, authorship, and/or publication of this article.

Ethical approval All animal experiments were performed in accordance with the Ministry of Science and Technology of China protocol for the care and use of laboratory animals and approved by the Scientific Ethics Committee of Huazhong Agricultural University (permit number HZAURA-2018-012).

\section{References}

1. Fisher CR, Streicker DG, Schnell MJ (2018) The spread and evolution of rabies virus: conquering new frontiers. Nat Rev Microbiol 16(4):241-255. https://doi.org/10.1038/nrmicro.2018.11

2. Fooks AR, Cliquet F, Finke S, Freuling C, Hemachudha T, Mani RS, Muller T, Nadin-Davis S, Picard-Meyer E, Wilde H, Banyard AC (2017) Rabies. Nat Rev Dis Prim 3:17091. https://doi. org/10.1038/nrdp.2017.91

3. Kelly RM, Strick PL (2000) Rabies as a transneuronal tracer of circuits in the central nervous system. J Neurosci Methods 103(1):63-71. https://doi.org/10.1016/s0165-0270(00)00296-X

4. Yamaoka S, Ito N, Ohka S, Kaneda S, Nakamura H, Agari T, Masatani T, Nakagawa K, Okada K, Okadera K, Mitake H, Fujii $\mathrm{T}$, Sugiyama M (2013) Involvement of the rabies virus phosphoprotein gene in neuroinvasiveness. J Virol 87(22):12327-12338. https://doi.org/10.1128/jvi.02132-13

5. Charlton KM, Casey GA (1981) Experimental rabies in skunks: persistence of virus in denervated muscle at the inoculation site. Can J Comp Med 45(4):357-362

6. Scott TP, Nel LH (2016) Subversion of the immune response by rabies virus. Viruses 8(8):231. https://doi.org/10.3390/v8080231

7. Schnell MJ, McGettigan JP, Wirblich C, Papaneri A (2010) The cell biology of rabies virus: using stealth to reach the brain. Nat Rev Microbiol 8(1):51-61. https://doi.org/10.1038/nrmicro2260
8. Thoulouze MI, Lafage M, Schachner M, Hartmann U, Cremer H, Lafon M (1998) The neural cell adhesion molecule is a receptor for rabies virus. J Virol 72(9):7181-7190

9. Lafon M (2005) Rabies virus receptors. J Neurovirol 11(1):82-87. https://doi.org/10.1080/13550280590900427

10. Tuffereau C, Benejean J, Blondel D, Kieffer B, Flamand A (1998) Low-affinity nerve-growth factor receptor (P75NTR) can serve as a receptor for rabies virus. EMBO J 17(24):7250-7259. https:// doi.org/10.1093/emboj/17.24.7250

11. Katz ISS, Guedes F, Fernandes ER, Dos Ramos SS (2017) Immunological aspects of rabies: a literature review. Arch Virol 162(11):3251-3268. https://doi.org/10.1007/s00705-017-3484-0

12. Li Y, Zhou M, Luo Z, Zhang Y, Cui M, Chen H, Fu ZF, Zhao L (2017) Overexpression of interleukin-7 extends the humoral immune response induced by rabies vaccination. J Virol 91(7):e02324-e12316. https://doi.org/10.1128/jvi.02324-16

13. Fooks AR, Banyard AC, Horton DL, Johnson N, McElhinney LM, Jackson AC (2014) Current status of rabies and prospects for elimination. Lancet 384(9951):1389-1399. https://doi. org/10.1016/s0140-6736(13)62707-5

14. Metlin A, Botvinkin AD, Elakov A L, Gruzdev KN (2019) Cases of human convalescence from rabies and lifetime diagnostics of lyssavirus encephalitis. Vopr Virusol 64(1):42-48. https://doi.org/10.18821/0507-4088-2019-64-1-42-48

15. de Souza A, Madhusudana SN (2014) Survival from rabies encephalitis. J Neurol Sci 339(1-2):8-14. https://doi. org/10.1016/j.jns.2014.02.013

16. Durr S, Naissengar S, Mindekem R, Diguimbye C, Niezgoda M, Kuzmin I, Rupprecht CE, Zinsstag J (2008) Rabies diagnosis for developing countries. PLoS Negl Trop Dis 2(3):e206. https ://doi.org/10.1371/journal.pntd.0000206

17. Prabhu KN, Isloor $S$, Veeresh $B H$, Rathnamma D, Sharada $R$, Das LJ, Satyanarayana ML, Hegde NR, Rahman SA (2018) Application and comparative evaluation of fluorescent antibody, immunohistochemistry and reverse transcription polymerase chain reaction tests for the detection of rabies virus antigen or nucleic acid in brain samples of animals suspected of rabies in India. Vet Sci 5(1):24. https://doi.org/10.3390/vetsci5010024

18. Faye M, Dacheux L, Weidmann M, Diop SA, Loucoubar C, Bourhy H, Sall AA, Faye O (2017) Development and validation of sensitive real-time RT-PCR assay for broad detection of rabies virus. J Virol Methods 243:120-130. https://doi. org/10.1016/j.jviromet.2016.12.019

19. Aravindhbabu RP, Manoharan S, Ramadass P (2014) Diagnostic evaluation of RT-PCR-ELISA for the detection of rabies virus. Virusdisease 25(1):120-124. https://doi.org/10.1007/s1333 7-013-0184-6 
20. Aravindh Babu RP, Manoharan S, Ramadass P, Chandran ND (2012) Evaluation of rt-PCR assay for routine laboratory diagnosis of rabies in post mortem brain samples from different species of animals. Indian J Virol 23(3):392-396. https://doi. org/10.1007/s13337-012-0109-9

21. Damodar T, Mani RS, Prathyusha PV (2019) Utility of rabies neutralizing antibody detection in cerebrospinal fluid and serum for ante-mortem diagnosis of human rabies. PLoS Negl Trop Dis 13(1):e0007128. https://doi.org/10.1371/journal.pntd.00071 28

22. Mani RS, Madhusudana SN, Mahadevan A, Reddy V, Belludi AY, Shankar SK (2014) Utility of real-time Taqman PCR for antemortem and postmortem diagnosis of human rabies. J Med Virol 86(10):1804-1812. https://doi.org/10.1002/jmv.23814

23. Realegeno S, Niezgoda M, Yager PA, Kumar A, Hoque L, Orciari L, Sambhara S, Olson VA, Satheshkumar PS (2018) An ELISA-based method for detection of rabies virus nucleoprotein-specific antibodies in human antemortem samples. PLoS ONE 13(11):e0207009. https://doi.org/10.1371/journ al.pone.0207009

24. Gootenberg JS, Abudayyeh OO, Lee JW, Essletzbichler P, Dy AJ, Joung J, Verdine V, Donghia N, Daringer NM, Freije CA, Myhrvold C, Bhattacharyya RP, Livny J, Regev A, Koonin EV, Hung DT, Sabeti PC, Collins JJ, Zhang F (2017) Nucleic acid detection with CRISPR-Cas13a/C2c2. Science 356(6336):438-442. https:// doi.org/10.1126/science.aam9321

25. Tian B, Zhou M, Yang Y, Yu L, Luo Z, Tian D, Wang K, Cui M, Chen H, Fu ZF, Zhao L (2017) Lab-attenuated rabies virus causes abortive infection and induces cytokine expression in astrocytes by activating mitochondrial antiviral-signaling protein signaling pathway. Front Immunol 8:2011. https://doi.org/10.3389/fimmu .2017.02011

26. Tian D, Luo Z, Zhou M, Li M, Yu L, Wang C, Yuan J, Li F, Tian B, Sui B, Chen H, Fu ZF, Zhao L (2016) Critical role of $\mathrm{K} 1685$ and $\mathrm{K} 1829$ in the large protein of rabies virus in viral pathogenicity and immune evasion. J Virol 90(1):232-244. https ://doi.org/10.1128/jvi.02050-15

27. Myhrvold C, Freije CA, Gootenberg JS, Abudayyeh OO, Metsky HC, Durbin AF, Kellner MJ, Tan AL, Paul LM, Parham LA, Garcia KF, Barnes KG, Chak B, Mondini A, Nogueira ML, Isern S, Michael SF, Lorenzana I, Yozwiak NL, MacInnis BL, Bosch I, Gehrke L, Zhang F, Sabeti PC (2018) Field-deployable viral diagnostics using CRISPR-Cas13. Science 360(6387):444-448. https://doi.org/10.1126/science.aas8836

28. Hayman DT, Banyard AC, Wakeley PR, Harkess G, Marston D, Wood JL, Cunningham AA, Fooks AR (2011) A universal realtime assay for the detection of Lyssaviruses. J Virol Methods 177(1):87-93. https://doi.org/10.1016/j.jviromet.2011.07.002

29. Deubelbeiss A, Zahno ML, Zanoni M, Bruegger D, Zanoni R (2014) Real-time RT-PCR for the detection of Lyssavirus species. J Vet Med 2014:476091. https://doi.org/10.1155/2014/476091

30. Granados-Riveron JT, Aquino-Jarquin G (2018) CRISPRCas 13 precision transcriptome engineering in cancer. Cancer Res 78(15):4107-4113. https://doi.org/10.1158/0008-5472. CAN-18-0785

31. Qin P, Park M, Alfson KJ, Tamhankar M, Carrion R, Patterson JL, Griffiths A, He Q, Yildiz A, Mathies R, Du K (2019) Rapid and fully microfluidic ebola virus detection with CRISPR-Cas13a. ACS Sens 4(4):1048-1054. https://doi.org/10.1021/acssensors $.9 b 00239$

32. Chang Y, Deng Y, Li T, Wang J, Wang T, Tan F, Li X, Tian K (2019) Visual detection of porcine reproductive and respiratory syndrome virus using CRISPR-Cas13a. Transbound Emerg Dis 00:1-8. https://doi.org/10.1111/tbed.13368

33. Kanitchinda S, Srisala J, Suebsing R, Prachumwat A, Chaijarasphong T (2020) CRISPR-Cas fluorescent cleavage assay coupled with recombinase polymerase amplification for sensitive and specific detection of Enterocytozoon hepatopenaei. Biotechnol Rep (Amsterdam, Netherlands) 27:e00485. https://doi.org/10.1016/j. btre.2020.e00485

34. He Q, Yu D, Bao M, Korensky G, Chen J, Shin M, Kim J, Park M, Qin P, Du K (2020) High-throughput and all-solution phase African Swine Fever Virus (ASFV) detection using CRISPR-Cas12a and fluorescence based point-of-care system. Biosens Bioelectron 154:112068. https://doi.org/10.1016/j.bios.2020.112068

35. Yin K, Ding X, Li Z, Zhao H, Cooper K, Liu C (2020) Dynamic aqueous multiphase reaction system for one-pot CRISPR-Cas12abased ultrasensitive and quantitative molecular diagnosis. Anal Chem 92(12):8561-8568. https://doi.org/10.1021/acs.analc hem.0c01459

36. Broughton JP, Deng X, Yu G, Fasching CL, Servellita V, Singh J, Miao X, Streithorst JA, Granados A, Sotomayor-Gonzalez A, Zorn K, Gopez A, Hsu E, Gu W, Miller S, Pan CY, Guevara H, Wadford DA, Chen JS, Chiu CY (2020) CRISPR-Cas12-based detection of SARS-CoV-2. Nat Biotechnol. https://doi.org/10.1038/s4158 7-020-0513-4

37. Guo L, Sun X, Wang X, Liang C, Jiang H, Gao Q, Dai M, Qu B, Fang S, Mao Y, Chen Y, Feng G, Gu Q, Wang RR, Zhou Q, Li W (2020) SARS-CoV-2 detection with CRISPR diagnostics. Cell Discov 6:34. https://doi.org/10.1038/s41421-020-0174-y

38. Patchsung M, Jantarug K, Pattama A, Aphicho K, Suraritdechachai S, Meesawat P, Sappakhaw K, Leelahakorn N, Ruenkam T, Wongsatit T, Athipanyasilp N, Eiamthong B, Lakkanasirorat B, Phoodokmai T, Niljianskul N, Pakotiprapha D, Chanarat S, Homchan A, Tinikul R, Kamutira P, Phiwkaow K, Soithongcharoen S, Kantiwiriyawanitch C, Pongsupasa V, Trisrivirat D, Jaroensuk J, Wongnate T, Maenpuen S, Chaiyen P, Kamnerdnakta S, Swangsri J, Chuthapisith S, Sirivatanauksorn Y, Chaimayo C, Sutthent R, Kantakamalakul W, Joung J, Ladha A, Jin X, Gootenberg JS, Abudayyeh OO, Zhang F, Horthongkham N, Uttamapinant C (2020) Clinical validation of a Cas13-based assay for the detection of SARS-CoV-2 RNA. Nat Biomed Eng. https://doi.org/10.1038/ s41551-020-00603-X

39. Shan Y, Zhou X, Huang R, Xing D (2019) High-fidelity and rapid quantification of miRNA combining crRNA programmability and CRISPR/Cas13a trans-cleavage activity. Anal Chem 91(8):52785285. https://doi.org/10.1021/acs.analchem.9b00073

40. Baerwald MR, Goodbla AM, Nagarajan RP, Gootenberg JS, Abudayyeh OO, Zhang F, Schreier AD (2020) Rapid and accurate species identification for ecological studies and monitoring using CRISPR-based SHERLOCK. Mol Ecol Resour. https://doi. org/10.1111/1755-0998.13186

41. McElhinney LM, Marston DA, Brookes SM, Fooks AR (2014) Effects of carcase decomposition on rabies virus infectivity and detection. J Virol Methods 207:110-113. https://doi.org/10.1016/j. jviromet.2014.06.024

42. Zhang G, Wang H, Mahmood F, Fu ZF (2013) Rabies virus glycoprotein is an important determinant for the induction of innate immune responses and the pathogenic mechanisms. Vet Microbiol 162(2-4):601-613. https://doi.org/10.1016/j.vetmic.2012.11.031

43. Conzelmann KK, Cox JH, Schneider LG, Thiel HJ (1990) Molecular cloning and complete nucleotide sequence of the attenuated rabies virus SAD B19. Virology 175(2):485-499. https://doi. org/10.1016/0042-6822(90)90433-r

44. Zhang G, Fu ZF (2012) Complete genome sequence of a street rabies virus from Mexico. J Virol 86(19):10892-10893. https:// doi.org/10.1128/jvi.01778-12

45. Faber M, Pulmanausahakul R, Nagao K, Prosniak M, Rice AB, Koprowski H, Schnell MJ, Dietzschold B (2004) Identification of viral genomic elements responsible for rabies virus neuroinvasiveness. Proc Natl Acad Sci USA 101(46):16328-16332. https://doi. org/10.1073/pnas.0407289101 
46. Yu F, Zhang G, Xiao S, Fang L, Xu G, Yan J, Chen H, Fu ZF (2012) Complete genome sequence of a street rabies virus isolated from a rabid dog in China. J Virol 86(19):10890-10891. https:// doi.org/10.1128/jvi.01775-12

47. Jiang Y, Yu X, Wang L, Lu Z, Liu H, Xuan H, Hu Z, Tu C (2008) An outbreak of pig rabies in Hunan province, China. Epidemiol Infect 136(4):504-508. https://doi.org/10.1017/s09502688070088 74

48. Heinemann MB, Fernandes-Matioli FM, Cortez A, Soares RM, Sakamoto SM, Bernardi F, Ito FH, Madeira AM, Richtzenhain LJ (2002) Genealogical analyses of rabies virus strains from Brazil based on N gene alleles. Epidemiol Infect 128(3):503-511. https ://doi.org/10.1017/s095026880200688x

49. Fischer S, Freuling CM, Müller T, Pfaff F, Bodenhofer U, Höper D, Fischer M, Marston DA, Fooks AR, Mettenleiter TC, Conraths FJ, Homeier-Bachmann T (2018) Defining objective clusters for rabies virus sequences using affinity propagation clustering. PLoS Negl Trop Dis 12(1):e0006182. https://doi.org/10.1371/journ al.pntd.0006182
50. Kuzmin IV, Shi M, Orciari LA, Yager PA, Velasco-Villa A, Kuzmina NA, Streicker DG, Bergman DL, Rupprecht CE (2012) Molecular inferences suggest multiple host shifts of rabies viruses from bats to mesocarnivores in Arizona during 2001-2009. PLoS Pathog 8(6):e1002786. https://doi.org/10.1371/journal.ppat.10027 86

51. Streicker DG, Turmelle AS, Vonhof MJ, Kuzmin IV, McCracken GF, Rupprecht CE (2010) Host phylogeny constrains cross-species emergence and establishment of rabies virus in bats. Science 329(5992):676-679. https://doi.org/10.1126/science.1188836

52. Rohde RE, Mayes BC, Smith JS, Neill SU (2004) Bat rabies, Texas, 1996-2000. Emerg Infect Dis 10(5):948-952. https://doi. org/10.3201/eid1005.030719

Publisher's Note Springer Nature remains neutral with regard to jurisdictional claims in published maps and institutional affiliations. 